臨床

副腎皮質ホルモン薬投与により高カリウム血症性

周期性四肢麻痺発作を抢こした 1 症例

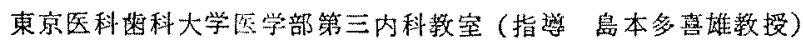 \\ 沼野 藤夫 久保田昌良橘田 鉄也 \\ 石泪 忠夫 前沢 秀憲

\section{A CASE OF HYPERKALEMIC PERIODIC PARALYSIS INDUCED BY ADMINISTRATION OF SYNTHETIC CORTICOSTEROIDS}

\author{
Fujio Numano, Akiyoshi Kubota, Tetsuya Kitta, \\ Tadao Ishioka and Hidenori Maezawa \\ The Third Department of Internal Medicine \\ Tokyo Medical and Dental University, School of Medicine
}

(Director: Prof. Takio Shimamoto)

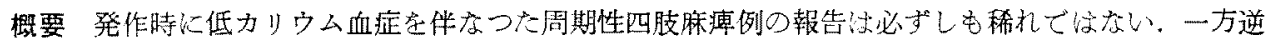
に高カリウム血症存伴なう症例もTylerらの報告以来adynamia episodica hereditariaとして発表され ているが，乙の频度住少なく，乙とに遗伝的関係のない症例灿著しく稀机とされる。最近副腎皮質不

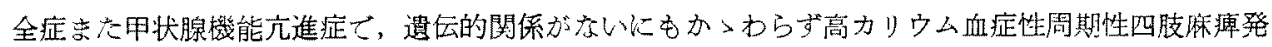

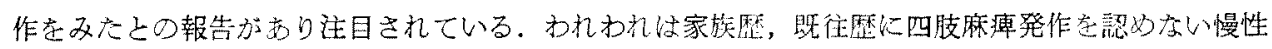
腎炎の患者にdexamethasone $2 \mathrm{mg}$ 筋注し，そのつ上゙弛綏性麻瘦が四肢柆より出現し，極期には四 肢の完全な弛䌊性麻疸, 軽度呼吸困難, 眼瞼下垂を来たし, 血清力リウム伯が $9.8 \mathrm{mEq} / l$ 高值に達

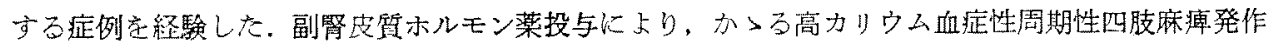
が誘発された報告㞲未だみあたら京いので報告する。
\end{abstract}

緒言

副腎皮質ホルモン蒋が臨床上広範囲に応用され るようになつて以来, 長期かつ大量の投与はしば しば種々の副作用を誘発することが明らかとな り，その病熊および対策についての関心も高まつ ている。

近年副腎皮質ホルモン蒋投与により筋力の低下 とやせを特徴とする筋障害が多く報告され“Steroid Myopathy"1)ー3)として注目されているが， 副腎皮賀ホルモン薬の投与により高カリウム血症 性周期性四肢麻痺発作が諳発されたとの埌告はな

昭和 41 年10月 8 日 第179回関東地方会推薦
い. 最近著者らは慢性腎炎末期の患者に拀いて， 副腎皮質ホルモン蓕投与により四䝸および眼䀫筋 の麻疾発作が稳発され呼吸困難をも伴なつた症例 を経験した，しかも本例では麻瘦の進行とともに 高力りウム血症などが興味ある経過を示した。

症 例

患者：○村○三子，女，21才，化粈品工場工 員.

家族歷：特記すへき家族的ないし遗伝的疾患 はない。

既往歷：特記すへさことはない。

現病歴：昭和40年 2 月22日勤務中突然覀心， 
表 1 。臨林检查成維

\begin{tabular}{|c|c|c|c|c|}
\hline & & $\begin{array}{c}\text { A ) 入院時 } \\
\text { (28/June1965) }\end{array}$ & $\begin{array}{l}\text { B ) 重症時 } \\
\text { (15/Sep. } 1965\end{array}$ & $\begin{array}{l}\text { C) 発作㭙 } \\
\text { (6/June1966) }\end{array}$ \\
\hline 再 & $(\mathrm{kg})$ & 42.5 & 52.0 & 36.5 \\
\hline 正 & (millg) & & & \\
\hline \multirow{3}{*}{ 赤 } & $30^{\prime}$ (m) & 71 & 53 & 18 \\
\hline & $1^{\circ}$ & 122 & 95 & 44 \\
\hline & $2^{\circ}$ & 143 & 136 & 78 \\
\hline \multirow{14}{*}{ 血 液検 查 } & $\mathrm{Hb} \quad(\%)$ & 52 & 56 & 46 \\
\hline & $\mathrm{Ht} \quad(\%)$ & & 18 & 28 \\
\hline & $\mathrm{RBC} \quad\left(\times 10^{4}\right)$ & 250 & 353 & 218 \\
\hline & $\mathrm{Cl}$ & 1.0 & 0.7 & 0.8 \\
\hline & WBC & 7500 & 14000 & 6800 \\
\hline & Neutro. Band $(\%)$ & 8 & & 7 \\
\hline & Segment & 53 & & 48 \\
\hline & Eosino. & 1 & & 2 \\
\hline & Baso. & 0 & & 0 \\
\hline & Mono. & 11 & & 10 \\
\hline & Lympho. & 25 & & 34 \\
\hline & One Stage Proth. T & $(82 \%)$ & & \\
\hline & Ca-clotting $\mathrm{T}$ & 136 & & \\
\hline & PTT & 41.6 & & \\
\hline \multirow{7}{*}{ 旰機能榆查 } & Meulengracht & 6 & & \\
\hline & TTT & 3.7 & 0.7 & 5.9 \\
\hline & $\mathrm{ZnTT}$ & 2.3 & 8.4 & 9.9 \\
\hline & GOT (unit) & 11 & 5 & 15 \\
\hline & GPT (unit) & 7 & 14 & 11 \\
\hline & Al-P-ase (KA unit) & 10.6 & & 7.8 \\
\hline & T. Cholesterol (mg/di) & 280 & 465 & 192 \\
\hline \multirow{6}{*}{ 血 清蛋白 } & $\mathrm{TP}(\mathrm{g} / \mathrm{d} 1)$ & 5.0 & 5.0 & 7.7 \\
\hline & $\mathrm{A} / \mathrm{G}$ ratio & 0.5 & 0.3 & 0.5 \\
\hline & Albumin $\quad(\%)$ & 24.3 & 22.8 & 45.2 \\
\hline & Globulin $\alpha(\%)$ & 22.2 & 25.3 & 18.7 \\
\hline & $\beta(\%)$ & 26.2 & 17.5 & 8.3 \\
\hline & $\gamma(\%)$ & 27.1 & 34.4 & 27.8 \\
\hline \multirow{3}{*}{ 血清䉓解貎 } & $\mathrm{Na} \quad(\mathrm{mEq} / \mathrm{l})$ & 139 & 139 & 138 \\
\hline & $\mathrm{K} \quad(\mathrm{mEq} / \mathrm{l})$ & 3.9 & 6.2 & 7.2 \\
\hline & $(\mathrm{mEq} / \mathrm{l})$ & 108 & 115 & 110 \\
\hline
\end{tabular}

呕吐を伴なう上腹部痛発作がおこり，某病院に救

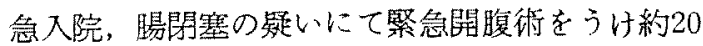
日間の経過で退院した。

同年 3 月27日再び覀心，呕吐，上腹部痛発作上 ともに吐血し前記病院に再入院，対症燎法をうけ 約 2 日間で前記症状は軽快した。しかし第 3 病日 より血尿が出現し，以後種々の治療に抗して漸次
増恶，ついには原は注とんど真赤というほどにも なり，顔面および下喵に浮腫が生じ，血圧が上昇 して来た〉め同年 6 月26日に当内科に転科した。

入院時所見：体格，栄養上もに中等度，体温 $36.6^{\circ} \mathrm{C}$, 服拍60/分整, 緊張良, 血圧150/80mmitg, 䫝面荅白，顔面および下肢に浮腫かなり著明，眼 睔および口腔粘膜は費血状，全身の表在性リンパ 
表 1 、㹂床検查成維（つふき）

\begin{tabular}{|c|c|c|c|c|}
\hline & & $\begin{array}{c}\text { A) 入院時 } \\
\text { (28/June1965) }\end{array}$ & $\begin{array}{c}\text { B) 重症胠 } \\
\text { (15Sep. 1965) }\end{array}$ & $\begin{array}{l}\text { C) 発作㗍 } \\
\text { ( 6/June1966) }\end{array}$ \\
\hline \multirow{2}{*}{ 等機能検查 } & Urea $\mathrm{N}$ & 36.0 & 115 & 78.5 \\
\hline & PSP test & & & 計 $5 \%$ 以下 \\
\hline \multirow{11}{*}{ 尿 検 查 } & Volume $\quad(\mathrm{ml} / \mathrm{day})$ & 950 & 1100 & 2200 \\
\hline & SG & 1018 & 1014 & 1009 \\
\hline & Color & reddish & thin yellow & yellow \\
\hline & Reaction & acid & $\overline{\text { acid }}$ & acid \\
\hline & (g/day) & 6.0 & 4.4 & 3.9 \\
\hline & Sugar & $(-)$ & $(-)$ & $(-)$ \\
\hline & Urobilinogen & $(+)$ & $(+)$ & $(+)$ \\
\hline & Sediment RBC & numerous & $15 \sim 20 / 1 \mathrm{~S} \mathrm{~F}$ & $2 \sim 5 / 1 \mathrm{SF}$ \\
\hline & WBC & $10 / 1 \mathrm{SF}$ & $5 \sim 10 / 1 \mathrm{SF}$ & $5 \sim 6 / 1 \mathrm{SF}$ \\
\hline & Epithelial Cell & $(H)$ & $(+)$ & $(+)$ \\
\hline & Crystals & $(+)$ & $(+)$ & $(+)$ \\
\hline \multirow{2}{*}{ 輁健㭘查 } & Ova & $(-)$ & $(-)$ & $(-)$ \\
\hline & Occult & $(-)$ & $(-)$ & $(-)$ \\
\hline \multirow{2}{*}{$\begin{array}{l}\text { 尿中おル } \\
\text { チ 定量 }\end{array}$} & 17-OHCS (mg/day) & & 0.9 & 0.8 \\
\hline & $(\mathrm{mg} / \mathrm{day})$ & & 0.7 & 0.5 \\
\hline
\end{tabular}

節は触れなかつた。心浊音界は左が左鎖骨中線よ り 1 横指外方のほかは正，心雑音なし，胸部の聴 診所見に異常なく, 腹部は平坦, 軟, 旰, 脾、腎 は触知されなかつた，四肢琏反射はすへて正常， 病的反射なく，知覚障害，運動障害は認められな 加った。

入院時検查成續： 表1に示すごとく，正色素 性貧血（血色素 $52 \%$ ，赤血球 250万)を示したが 白血球百分率には变化なく，凝固系にも異常は認 められなかつた，盰機能検查成績は正常筙囲内に あつたが血清総蛋白は著明に低下し，分画ではア ルブミンの減少， ターグロブリンの增加傾向がみら， れた．尿は全く血液そのものといつてよいほどの 血尿を呈し，蛋白尿も高度で 1 日蛋白量 $6 \sim 8 \mathrm{~g}$ であつた，腎機能検查では尿素窒素は $36.0 \mathrm{mg} / \mathrm{dl}$ と軽度上界した。膀胱鏡検查で両側尿管口からの 出血が確かめられたが，インシゴカ、ン排泄時 閒はほほ正常，逆行性腎孟撮影でとくに異常は認 められなかつた。電図検查, 胸部X線所見, 胃 腸管X線検查で特記すべき異常は認められなかつ た.

入院後の経過：強度の血尿㧍よび蛋白尿, 貧 血，腎機能障害に対し，各種利尿楽，副腎皮質ホル モン薬(prednisolone 30〜 50mg/day), 抗生物質,
止血薬などを投与したところ血尿は入院後約 1 力 月半にて 1 視野 $(\times 400)$ 10個程度にまで改善され た.しかし $5 \sim 7 \mathrm{~g} /$ dayの尿蛋白が続き，全身の 浮腫の増強，貧血も徐々に高度となり，血圧も漸 次上昇, 血清尿素空素值, 血清総コレステロール の㴖增、腹水の出現上一般状態はむしろ悪化を示 した.

入院 3 力月後の 9 月末ごろにおいては一般状熊 は極度に悪化し，全身の浮腫，腹水坾留きわめて 高度であり，血圧も 210～190/130 110 $\mathrm{mmHg}$ と上 昇し，たびたび全身性の強直性痤攀発作をみた。 このころの臨床検査成績は表 1 の 項にみるよう に，血清総コレステロール值 ( $465 \mathrm{mg} / \mathrm{dl})$, 血清 尿素空素值 $(115 \mathrm{mg} / \mathrm{dl})$ と上昇が著明であつた。 これに対し，副腎皮質ホルモン薬，抗生物質，利 尿薬，降圧薬に強心薬，また赤血球浮遊液，新 鮮血輸血，腹膜穿刺等の対症療法を行なつたとこ ろ，このころを頂点として一般状態は豕次改善さ れ，昭和 41 年春ごろよりは離床，元気に病室内を 歩きまわることができる注どになつた。表 1 の 項にみるように血清蛋白，血清総コレステロール 値等は改善されて来ていたが，依然尿蛋白は 3 〜 $4 \mathrm{~g} /$ dayであり，血清カリウム值は $6 \sim 7 \mathrm{mEq} / l$ と 上昇し，負血は血色素46\%であり，蛋白尿性網膜 
表 2

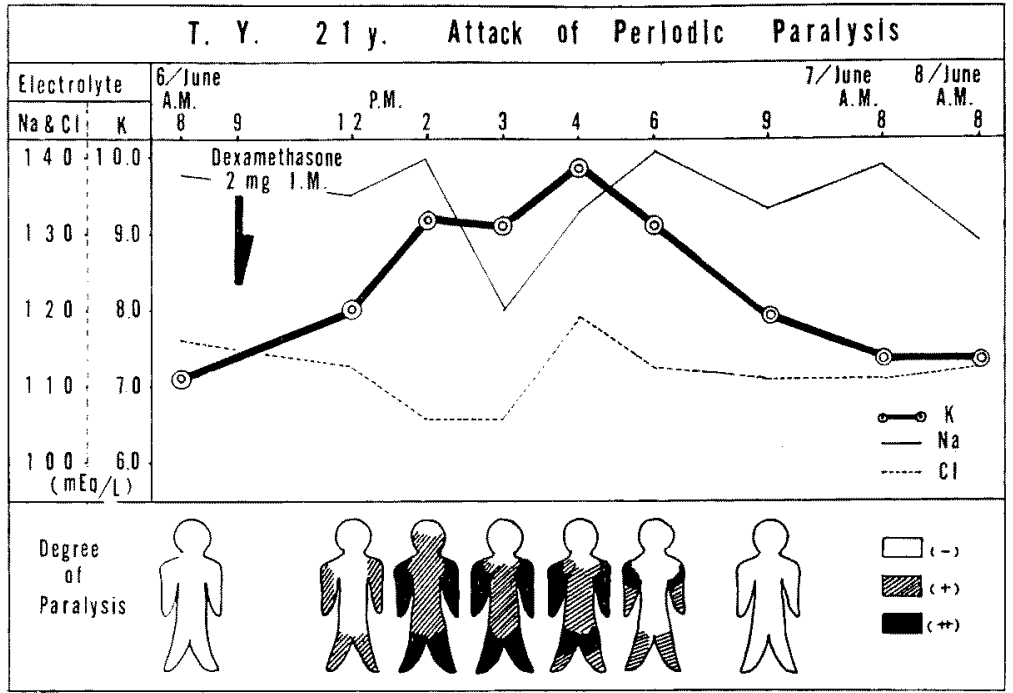

炎の出現をみた。PS P 試験では 2 時間の全排泄 量は $5 \%$ 以下であつた，浮腫の消退につれ筋肉萎 縮が目立つてきたが，このころでは全身とくに四 肢および腰部の筋萎縮は著明なものがあつた。

周期性四肢麻瘏発作：入院当初上り副腎皮貿 ホルモン薬としてprednisolone30～50mgを症状に 応じて增減しながら使用していたが，12月初旬よ り，激しい強直性痤攀，高拻 $\left(40.2^{\circ} \mathrm{C}\right)$ ，心衰弱の 重症時にdexamethasone $4 \sim 8 \mathrm{mg}$ 点滴投与をこ れに加えた，それ以後副腎皮質ホルモン蕌として dexamethasoneを使用し $2 \sim 4 \mathrm{mg}$ 経口または筋 注にて投与していたが，一般症状の好転とともに 経口投与のみに切りか元4月以降6月までは利尿 薬hydrochlorothiazide $100 \mathrm{mg} \varepsilon と も に 2 \mathrm{mg}$ (朝夕 2 回）経口投与が行なわれていた。

6 月上旬患者が胃腸障害を訴えたのでdexamethasone 2 mg 筋注に切り換えたところ，注射 後 3 時間目ころより頭痛, 全身倦急感とともに四 䁌の脱力感につついて四肢末端部に弛緩性四䁌麻 瘏発作がおこり急速に上行した。この際血清カリ ウム值はとくに採血，測定上過誤はないと思われ るのに $14 \mathrm{mEq} / l$ と著しい高值であつた。しかし麻 痺は約 3 時間の経過で何ら処置をほごこすことな しに緩解した。
この麻痺発作と副腎皮質ホルモン䕨との関係を 確かめるために，翌日1日副腎皮質ホルモン薬を 投与しないで観察，四肢になんらの異常も特別な 主訴もないことを確かめた後，その翌朝再びdexa、 methasone 2 mg 筋注したところ再び同様な麻痺 の誘発されるのを観察した。すなわち，

午前 9 時； dexamethasone $2 \mathrm{mg}$ 筋注. 筋注前 の血清電解質はNa $138 \mathrm{mEq} / l, \mathrm{~K} 7.2 \mathrm{mEq} / l, \quad \mathrm{Cl}$ $116 \mathrm{mEq} / l$, 血生 $180 / 130 \mathrm{~mm} H$.

午前12時；全身の倦怠感, 頭痛を訴えた。両 側腱反射正常.

千後 1 時；隐㤐感はますます增強，ことに四 肢に著しい，膝蓋腱反射 (PTR) はほぐ正常で あつたがアキレス腱反射 (ATR) は両側とも減 弱，尺骨，橈骨反射もやs減弱していた。

午後 1 時 30 分; 睖関節以下の自発運動不能, 上肢は未だ動かしえた，琏反射すへて減弱，ATR $(-)$.

午後 2 時; 四肢は完全な弛緩性麻疩に宿り睷 反射は全て消失した．声が著しく力弱く言葉が聞 きとり難かつた．眼䀫は下垂し咬筋反射も著しく 減弱していた。軽い呼吸困難の出現もみられた。 血圧160/120m m Hg，血清カリウム值は $9.2 \mathrm{mEq} / l$ で あつた。 
表 3 。午後 2 特 30 分の時の心電图

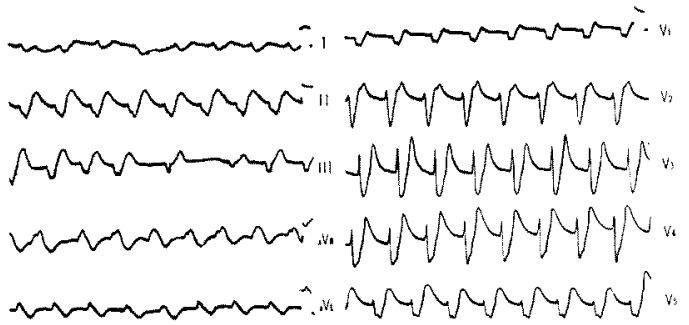

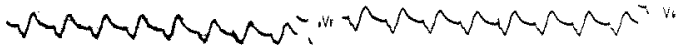

注： $\mathrm{PQ}$ 時間0.24 0.28秒, $\mathrm{QR} \mathrm{S}$ 時間0.38秒

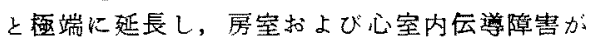
高度なことを示す。四肢誘尊撮獂時に心室自動 を思わせる不整脈括よび種々变形したQR S 群 む出現している。

午後 2 時 30 分；碩痛は多少改善されてきたが 四肢の弛緩性麻瘦, 発声障害, 軽度呼吸困難は依 然として続いていた．服拍に $2 \sim 3$ /分の結滞を 初めて諗めた。血仕162/124mm ，表 3 はこの時 の心電図であり $\mathrm{P}$ Q時間は $0.24 \sim 0.28$ 秒， QR S 時間は0.38秒と極端に延長し高度の房室および心 室内伝導障害の存在を示し，時に心室自動を思わ せる不整腿および種々变形したQR S 群の出現の 特徵が認められる。

午後 3 時；大分語調がしつかりしてきたが末 だ下頡部に疲学感を訴えていた。このころより 足指が動かせるようになつた，血清カリウム値は $9.1 \mathrm{mEq} / l$ と高值がつづいていたが $120 \mathrm{mEq} / l$ と 血清ナトリウム値の低下が注目された。血清クロ ール值は $96 \mathrm{mEq} / l$, 脈拍結滞は消失していた（表 4).

午後 3 時30分；足関節以下は自由に動加せる ようになつたが，睖関節は力一杯努力して辛うじ て動かし得る程度であつた。血圧166/128 $\mathrm{mm} \mathrm{Hg}$, 呼 吸困難, 頭痛も消失した。

午後 4 時；賕関節の動きは自由になつたが多 少重苦しい感じが残つていた，时関節，手関節は 自由に動かしえた. ATR, PTR (十)，血清力 リウム值 $9.8 \mathrm{mEq} / l, \quad$ ナトリウム值 $133 \mathrm{mEq} / l$, クロール值 $119 \mathrm{mEq} / l$, 血圧 $180 / 126 \mathrm{~mm} H g$.
表 4, 四肢麻瘨発作経過中の心骊図 （上段はI誘㸂，下段はV誘尊を示す）
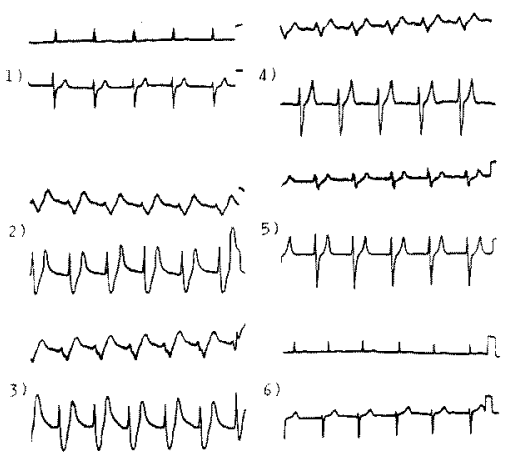

1) 午前 9 時； Dexamethasone $2 \mathrm{mg}$ 筋注前 (Serum K: $7.2 \mathrm{mEq} / \mathrm{l}$ )

2) 午後 2 斑; $\mathrm{PQ}$ 時間 0.22 秒, $\mathrm{QR} \mathrm{S}$ 時間 0.24 秒, 右脚ブロック様のQR S 群, T波の增 高と尖鋭化著明 (Serum K: $9.1 \mathrm{mEq} / l$ )

3）午後 3 時；2）に的ける特徽が持統してい ๖. (Serum K: $9.1 \mathrm{mEq} / l$ )

4) 午後 4 時; QR S 群の变形は次第に改善さ れて来た方胸部誘導のT波はいつ尖尖鋭化 し、幅のせまいいわゆる舆型的なテント状丁 を呈した。(Serum K: $9.8 \mathrm{mEq} / l$ )

5) 龶後6 時：(Serum K: $8.8 \mathrm{mEq} / l$ )

6) 将朝午培 8时： $\mathrm{PQ}$ 時間0.16秒， QR S 時 間0.08秒と正常範囲に愎した。 (Serum K: $7.2 \mathrm{mEq} / l)$

午後 5 時; 下肢では軽い傹急感あるのみで運 動はほとんど正常，上肢も肩関節に重い感じを残 すのみであつた。

午後 6 時：筋力はdexamethasone注射前 $と$ 全 く同じ状態に回復, 離床して病室内を歩くことも でき，食慨も自由に摄取した，心電図においてもQ R S 群の变形はしだいに改善されて来たが，胸部 誘導におけるT波は一そう尖鋭化し，幅もせまい いわゆるテント状 Tの曲型的な像を呈していた。

血清カリウム值は $8.8 \mathrm{mEq} / /$ とた高值を示して いた（表 2 ，表 3 ).

血清カリウム值は午前 9 時には $7.9 \mathrm{mEq} / l$, 翌 朝 8 時には $7.2 \mathrm{mEq} / l$ と元の值にまで回復し，心 電図も負荷前と差がほとんどないまでに改善され た(表 3 ).

S-GOT，S-GPTも経過をおつて測定したが，変 
動は譛められなかつた。

血清総蛋白量注 dexamethasone注 射前 $7.7 \mathrm{~g} / \mathrm{dl}$ であつたが，麻痺の進行とともに上昇傾向を示し 最高 $8.4 \mathrm{mg} / \mathrm{dl}$ (午後 3 時) に達したが麻瘦の回復 ととともに再び低下した。

われわれはその後さらにdexamethasone $1 \mathrm{mg}$ 筋

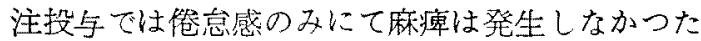
ことを確かめた。

\section{考案}

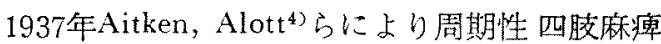
発作と低力リウム血症との関係が初めて注目され て以来，一般に低力リウム血症は本発作の特徽の 一つとさえされている5゙.

しかしその後本発作峘族的に発生するのみな らずいくつかの疾患に合併することが観察され6) 7)，さらにはTyler，Stevensらにより麻痺発作中逆 に高为り血症を示す症例も報告されるように

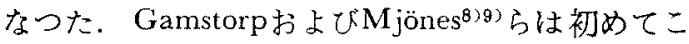
れにadynamia episodica hereditaria と命名して従 来の周期性四肢麻疩と区别し，以後Eganら，McArdle, Armstrongらによる発表がある。そのほとん どすへてで遺伝的関係吕認められ，本症における 特徽ともされていた くに遺伝的な関係をなして高力リウム血症性周 期性四胶麻瘏発作をくり返した慢性副腎機能不全 症の 1 症例を報告し，わが国においても大营ら ${ }^{111}$ は甲状腺機能九准症に合併した周期性四㬵麻㽻 で，発作中に血清力リウム値が上昇した症例を報 告している。また。 Poskanzer ${ }^{122}$ (四肢麻痺発作中 血清カリウム值に変化をみない症例を報告した。

麻痺発作の発生機序にかんしてDanowski ${ }^{13)}$ は 麻痺発作時細胞外力リウムが細胞内に移行するこ とを証明し， Grob ${ }^{14}$ はこの細胞内外力リウム濃度 比の上昇に上る筇肉の静止膜電位の上昇が麻痺 を生ずるとするhyper-polarization blockを提唱し た。しかしCreutzfeld ${ }^{15}$ ) は周期性四肢麻瘏患者に おいて非発作特には筋静止膜電位は健 康人の值 $(-87.4 \pm 8.9 \mathrm{mV})$ とほぶ同じ值 $(-85.6 \pm 6.1$ $\mathrm{mV})$ を示しているが，四肢林痺発作時にはー77.1 $\pm 8.2 \mathrm{mV}$ と約ー $10 \mathrm{mV}$ 前後の低下を示しているこ とを実証しささらにはadynamia episodica hereditariaにおいても非発作時すでにわずかの低下 を示しているのにすぎいのが（-68.5士 5.9 $\mathrm{mV})$ ， 発作時にはー46.3土6.6mVといつそうの 低下を示していることを明らかにし，高カリウム 血症時，低カリウム血症時をとわず，麻痺は筋静 止膜電位の低下depolarization blockによることを 報告した，里吉ら ${ }^{16)}$ 同様な実験成績を報告し， かかる静止膜電位の低下はおそらく細胞内外のイ オン濃度差にのみよるのではなく，各イオンの細 胞膜透過性九進によつて生じたものであろうと述 べている17)18)

本症例は家族歷，既往歴に周期性四肢麻瘦発作 の認められない慢性腎炎の患者であり，長期間 prednisolone扔よびdexamethasoneにて治療中， dexamethasoneの筋注により上行性の四肢麻䝵発 作が出現し，その際血清カリウム值は $9.8 \mathrm{mEq} / \mathrm{l}$ にも達し，しかも何らの処置を汪どこすことなく して麻痺は自然に綏解し，血清カリウム值もまた 自然に低下を示した。

Mark㧍よびFeit ${ }^{19}$ ' はAddison病の患者について 発症時（crisis）に高力リウム血症による四肢麻 盘発作老報告し，以後数例の報告が記載されてい $ろ^{20)}$.

これらはすべて腎不全症に伴なう高カリウム血 症時には，しばしばみられる四肢麻痺と同じく非 回復性のものであつた。

しかし $\mathrm{Faw}^{10}$ は慢性副腎不全の患者で周期性四 肢麻瘦が反復し，自然回復をくり返した症例を報 告している.われわれの報告例においては長期間 副腎皮質ホルモン薬が投与され，そのための副腎 機能不全により麻痺が発生した可能性を考虑する 必要があろう。本症例は昭和 40 年 6 月入院以来, しばしば同量のdexamethasoneを筋注しても，四 肢麻痺発作㴡発されなかつたのに昭和 41 年 6 月 同量の筋注で確実に発作が誘発された，発作時と それ以前の患者の病態の差異については明らかで ない，副腎皮質機能と四肢麻盘との因果関係につ 
いては定説をえないが，少なくともこれに加わる 他の要因を考虑する必要がある。

本症例では発作誘発時には著しい筋肉萎縮がみ られ，この所見はそれ以前のdexamethasone筋注 時と明らかに区別された。したがつてかっる筋肉 に一封に大量の副腎皮質ホルモンが作用したこと による細胞膜透過性の一過性異常が四盿麻瘏発生 の原因とも考えられる，本症例にみられた筋萎縮 の成因は明らかでない，脣期の腎機能不全による 栄養障害も考應せ敉ばならな。しかし近年副腎 皮㙺ホルモン蒋の長期投与に上る“Steroid Myopathy”の報告が少なくなく，一般にdexamethasoneなど $\mathrm{C}_{9}-\mathrm{F}$-compoundによる発生が重視されて いる(1)2. 本症例 \& prednisolone $30 \sim 50 \mathrm{mg} / \mathrm{day} に て$ 約 4 力月，その後dexamethasone $2 \sim 4 \mathrm{mg} /$ dayに て3カ月治療を続けているのでいわゆる“Steroid Myopathy”をも考虑すべであろう。

\section{結 論}

Prednisolone斿よびdexamethasoneにて長期間 治療を続けていた慢性腎炎の患者にdexamethasone $2 \mathrm{mg}$ 筋注したところ侉㤐感，頭痛にひきつ づき 3 時間後より四肢末端に始まる弛緩性麻瘦発 作が生じ, 極期には四肢の完全な弛緩性麻檕, 発声 障害, 軽度呼吸困難, 眼倹下茾を示した。その際 血清力リウム值は $9.8 \mathrm{mEq} /$ に達し, 心電図では $\mathrm{PQ}$ 時間掞よびQR S 時間の延長, 不整脈の出現, Tの增高をみた，麻㾇はその後徐々に四肢末端部 上り消退し，麻㽻発生後 6 時間で全く回復した。 その翌々日dexamethasone $2 \mathrm{mg}$ 再び筋注し全く 同じような麻㾇発作の出現をみた。

なおこの登作は経口投与では誘発されなかつ た。家族歷, 既往歴に麻痺発作をみない本症例に おいて観察された高カリウム血症性周期性四肢麻
㾝であり，その発生機序については明らかでない

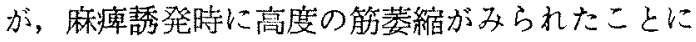
注目し若干の考察を試みた。

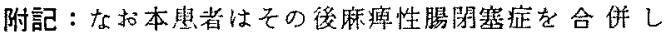
死亡，目下病理学的検索が行なわれている.

\section{参考文献}

1) Golding, D.N. \& Begg, T.B.: Brit. M.J., 1 : 1129, 1960. -2) Faludi, G., Mills, L.C. \& Chayes, Z.W.: Acta Endocr., 45 : 68, 1964. -3) Perkoff, G.T., Silber, R., Tyler, F.H.: Cartwright G.E. \& Wintrobe, M.M.: Amer. J. Med., $26: 891$, 1959. -4) Aitken, R.S., Alott, E.N., Castleden L.I.M. \& Walker, M.: Clin. Sci., 3 : 47, 1937。一5)沼野藤夫, 伊藤幸郎, 佐川宸夫, 前讯秀慧：内科， $15: 370 ， 1965 ，-6$ )鎮目和夫： 代謝， $2: 558,1965$ ，一7)紫芝主昆，任久間真樹， 鎮目和夫：日本瓳床，22：2502，1964。-8)Gamstorp, L., Hauge, M., Helweg-Larsen, H.F., Mjönes, H. \& Sagild, U.: Amer. J. Med., 23 : 358, 1957. -9)Stanburg, J.B., Wyngaarden, J.B. \& Fredrickson, D.S.: The Metabolic Basis of Inherited Disease: Chap. 28, 1960(McGraw-Hill New York/Toronto/London, 1960). -10) Faw, M.L. \& Ewer, R.W.: Ann. intern. Med., 57 : 455, 1962，一11）大菅俊明，牛尾耕一：日内会誌，52： 954, 1963. -12) Poskanzer, D.: Amer. J. Med 31 : 328,1961. -13) Danowski, T.S., Elkinton, J.R., Burrow, B.A. \& Winkler, A.W.: J. clin. Invest., $27: 65$. 1948. - -14) Grob, D., Johns, R.J. \& Lilyestrand, Ä.: Amer. J. Med., 23 : 356, 1957, -15) Creutzfeld, O.D., Abott, B.C., Fowler, W.M. \& Pearson, C.M.: Electroenceph. clin. Neurophysiol., $15: 508,1963,-16)$ 里吉営 二郎：郜本腷波，5:136，1953。一-17) 里吉営二 郎：日内会誌。53：1277，1965，一18）椿忠雄,

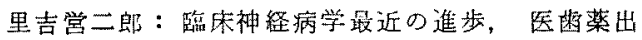
肘, 1965. - 19) Mark, L.J. \& Feit, E.: Arch. intern. Med., $91: 56$, 1953. -20) Pollen, R.H. \& Williams, R.H.: New Engl. J. Med., 263 : 273,1960 . 